DOI:http://dx.doi.org/10.24093/awejtls/vol1no2.13

\title{
Fictional Characters Outside Fiction: "Being" as a Fictional Character in Heidegger's Being and Time
}

\author{
Abdel-Fattah M. Adel \\ Department of English, College of Science and Arts \\ University of Bisha, Saudi Arabia
}

\begin{abstract}
Can non-fiction present fictional characters? This is the main question of this paper. In reading Martin Heidegger's Being and Time (1927), the readers construct a figure in their mind of a persona about whom all the philosophical reflections are discussed. Heidegger presents Dasein as a 'particular being' that characterizes all the features of human existence. Heidegger did not want to define and explain 'being', but he aimed at presenting a 'sense of being' in the form of characterizing the philosophical reflections he was presenting. After discussing how it can be claimed that Dasein can be considered a 'fictional character' in the absence of a 'plot,' the present article explains the main aspects through which a 'fictional character' is constructed, or figured out, in readers' mind. It tries, also, to show how and why Heidegger resorts to this technique of fictional characterization in this highly influential philosophical book. The article specifies four main personality models, that help construct Dasein as a 'fictional character' in the reader's mind. These personality models are: being-in-world, being-in-time, living-by-activity, and living-to-an-end. By ascribing such personality models to Dasein, Heidegger managed to present in his work a character that can be easily remembered all the time Being and Time is mentioned.
\end{abstract}

Key Words: being, character, characterization, fiction, Heidegger

Cite as: Adel,A.M. (2017). Fictional Characters Outside Fiction: "Being" as a Fictional Character in Heidegger's Being and Time. Arab World English Journal for Translation \& Literary Studies, 1(2). DOI:http://dx.doi.org/10.24093/awejtls/vol1no2.13 
AWEJ for Translation \& Literary Studies volume, 1 Number 2, May 2017

Fictional Characters Outside Fiction

Adel

\section{Introduction}

In reading Martin Heidegger's Being and Time (1927), one is aware all the time of the presence of a persona ${ }^{(1)}$ about whom all the philosophical ideas in the book are discussed. This aspect of the book turns the experience of reading the book to be closely similar to reading fiction. The way this persona is constructed in the book, the way it is conveyed to the reader, and the way the reader constructs an image of this persona while reading are all aspects of the fictional characters one can easily find in fictional narratives despite the fact that it is a non-literary work. It is the objective of this article, therefore, to explain the grounds on which it can be claimed that Heidegger's discussion in his book produces a character, and, at the same time, how and why he resorts to this technique of fictional characterization in this highly influential philosophical book.

Tackling a topic like this one confronts the question: is it possible to discuss the presence of literary elements, like character and characterization, in a non-literary work? In order to avoid the disputed demarcation between what is literary and what is non-literary, the following discussion will focus on a more specific version of the question: is it possible to find a character without a plot-based narrative? Another question to be considered is: is it important that a 'character' looks like a full human being? Finally, the question about what constitutes a 'character' in a reader's mind, and how this 'construct' is achieved, should be answered as well.

\section{Plotless Fictional Characters}

Most accounts of fiction since Aristotle, including the formalists and the structuralists, have subordinated character to plot (Weststeijn, 2004, p. 57). Henry James (1972), for example, expressed this stand saying: 'character in any sense in which we can get at it is action, and action is plot (p. 13). However, this subordination of the character as a function of the plot, is sometime challenged. Although Margolin (2007) defines 'character' as a term that 'refers to a storyworld participant, i.e., any individual or unified group occurring in a drama or work of narrative fiction,' he considers this restriction of the term to participants in the narrated domain as a narrower sense (pp. 66-69). In Story and Discourse (1980), Chatman divides the three elements of narrative under two headings: events and existents categorizing 'plot' under events and 'character' and 'setting' under existents (p. 19). Chatman follows the Structuralist theory that each narrative has two parts: a story and a discourse; both events and existents are listed under 'story.' Margolin (1986) explains this distinction in terms of 'do' for events and 'is' for existents, considering this division a 'convenience, not a logical absolute' (p. 218).

A similar categorization can be found in Rimmon-Kenan's Narrative Fiction: Contemporary Poetics (1983). She divides the narratological domain into three inter-dependent spheres: story, text and narration. 'Character,' in Rimmon-Kenan's division, is discussed with 'plot' under the level of the story (pp. 29-31). However, under the level of the text, she discussed 'characterization' along with 'time' and 'focalization' (pp. 59-60). Schwarz (1989) differentiates between 'character' and 'characterization' on the same bases. He considers 'characterization' a formal term, while 'character,' for him, belongs to 'content' or 'story' (p. 93).

Schwarz (1989) is not much interested in the issue of subordinating 'character' to 'plot,' but he refers to a general tendency in narrative studies to 'believe less in plots than we used to' (p. 93). He criticizes both stands: those who subordinate 'character' to 'plot' and those who separate 'character' from 'plot': 
When critics isolate characterization from language, setting, or plot, or when they see character only as a function of the action of a narrative-when they see characters simply as agents of action or agents acted upon - they often reduce character to either a verbal display (in the manner of deconstruction) or extricate it from the form of the Active world, thus blurring more than necessary the distinction between art and life. (p. 93)

Schwarz's objection applies to real narratives; what interests us, for the purpose of this study, is the indication we find in Chatman (1980), Rimmon-Kenan (1983) and Schwarz (1989) that there are, at least, some aspects of the narrative character, and the way it is characterized, that can be discussed separately from the events of the story.

The concept of 'character' is associated, to a great extent, with modern narratives, especially the novel. However, presenting characters in writing is considered a separate literary genre which became popular early in the 7th century before the beginning of the novelist's approach to character (Cuddon, 1999, p. 126). During that time, some writings, like Joseph Hall's Characters of Virtues and Vices (1608), discussed 'characters' based in the then well-established idea that man was an embodiment of the universe. Cuddon (1999) identifies three categories of those 'essay characters':

(a) a type - a self-conceited man, a blunt man; (b) a social type - an antiquary an old college butler; (c) a place or scene: a tavern or cockpit. The idea was to create an individual while formulating a type. There was usually an attempt at universality. For instance, a pretender to learning might be found in any part of the world at any time. ( $\mathrm{p}$. 126)

A major development came to this art as the writers took the process a stage further by naming the characters. Cuddon (1999) asserts that though these 'essay characters' represented types, they were also particular individuals. He concludes that 'the essay character gave place to and made possible the character of the novel' which, along with the portrayal of individuals, still presents some typical characters, like some of Charles Dickens's characters (p. 127).

This tendency towards universality might be the reason why 'character' is considered one of the most difficult terms in critical vocabulary to contain within the fictional environment (Bradbury, 2006, p. 24). Bradbury (2006) represents the modern sense of 'character' defining it as 'the fictional representation of a person.' However, he wonders how the idea of 'character' is attached to the personalizing or humanizing dimension of literature, but the representation of persons in literature is a simultaneous process of their humanization and their dehumanization at the same time. Two theoretical models of character, therefore, have emerged: the mimetic or representational model that treats character as a human or human-like entity; and the nonmimetic model that reduces it to a text-grammatical, lexical, thematic, or compositional unit (pp. 23-24).

The mimetic model, based on the traditional Aristotelian humanistic concept, came under attack in Structuralist and Poststructuralist writings, like Roland Barthes' and Hélène Cixous', for methodological and ideological reasons. They dissolved characters into a system of literary conventions and codes which are naturalized by the readers. Readers are said to project lifelikeness upon codified literary representations by assimilating them to their own prior 
stereotypes of individuals in real life. In "The Character of "Character," Cixous (1974) defines "character as "a Figure that can be used in semiotics: the "personage" functions as a social sign, in relation to other signs (p. 384). For Cixous, a "character" is to be' figured out' through some 'identification circuit with the reader' in which the more "character" fulfills the norms, the better the reader recognizes it (p. 385).

The idea of defining 'character' in the light of the reader's interpretation is echoed in Abrams' definition of the 'characters' as persons 'who are interpreted by the reader as being endowed with particular moral, intellectual, and emotional qualities' (Abrams, 1999, p. 32). Margolin (1986) provides a definition that contains one of the basics upon which characters are constituted:

'Character' or 'person' in narrative will be understood as designating a human or humanlike individual, existing in some possible world, ..., to whom inner states, mental properties (traits, features) or complexes of such properties (personality models) can be ascribed on the basis of textual data. (p. 205)

In this definition, a 'character' is referred to as a human-like figure that comes up in a reader's mind as they are reading. A 'character' is constituted in a reader's mind through some 'personality models' ascribed to it by the text. These models build up as the text provides details about that character: inner states, mental properties, traits and features.

The question related to how readers construct, or figure out, an image of a character is the focus of the cognitive approach in narrative theory. The character is perceived as a conceptual unit mentally generated by a reader in response to textual clues. The reader then establishes a distinct entity in his or her mental map to which features are ascribed on the basis of textual data. Once a certain number of properties have been gathered, they often activate a knowledge structure stored in long-term memory and integrated into a character model (Margolin, 2007, pp. 66-68).

The technique through which a writer provides the textual data to help the reader construct that figure in his/her mind is 'characterization.' For Schwarz (1989), 'character' does not exist without 'characterization.' Readers realize a 'character' by a pattern that forms the formal and linguistic embodiment of character. 'Characterization' provides the 'traits' in terms of which readers understand characters (pp. 89, 97). Chatman (1980) shows how in the course of reading a story we gradually construct a character by piecing together his or her personal qualities. These qualities are inferred from all kinds of textual data. He discusses 'character as a 'construct' in a reader's mind upon some qualities whether these qualities are provided as part of a narrative or a history book (pp. 117-118). Weststeijn (2004) explain Chatman's idea:

We construct a literary character (Hamlet) in the same way that we construct a historical person (Samuel Johnson) and we even 'construct' the people we meet in real life: We read between their lines, so to speak; we form hypotheses on the basis of what we know and see; we try to figure them out, predict their actions, and so on. (p. 57)

We do not remember characters, asserts Weststeijn, because of the words they say or the words used to describe them, but we remember them as constructs: 'sometimes vague and blurred, sometimes vivid and intense' in our consciousness (pp. 57-58). The way we form an image of the character is described by Chatman (1980) as a 'paradigm of traits,' defining a trait as a 
'relatively stable or abiding personal quality' (p. 126). James Phelan, as Weststeijn (2004) explains, prefers to use 'attributes' as the fundamental units of the character. A character's 'attributes' can make him or her a plausible person, a unique individual, but may at the same time have a thematic function. This function 'generalizes' the character so that he or she can be used to represent a certain idea, a group or a class within the semantic structure of the literary work (pp. 59-62).

If we encounter a piece of writing that helps us produce such an image, the reader figures out a person as he/she is reading, can we call it a 'character'? By the same token, if the writer managed to provide the reader with ample textual data that help him/her construct that image, can we consider this characterization? A reading of Heidegger's Being and Time can answer these questions.

\section{"Being" as a Fictional Character in Heidegger's Being and Time}

Based on his existential philosophy and his phenomenological approach, the German Philosopher Martin Heidegger (1889 - 1976) presented in his philosophical writings a deep analysis of the conditions of human existence. ${ }^{(2)} \mathrm{He}$ proposes to understand being itself, as distinguished from any specific beings. However, he is confronted with the fact that the question of 'being' is usually overlooked as obvious or indefinable in modern philosophy:

A dogma has been developed which not only declares the question about the meaning of Being to be superfluous, but sanctions its complete neglect. It is said that 'Being' is the most universal and the emptiest of concepts. As such it resists every attempt at definition. (Heidegger, 1962, p. 21)

In order to present an account of 'being' that can capture the 'universality' and, at the same time, fill the 'emptiness' of the concept, Heidegger (1962) resorts to presenting 'being' as a character in his work: 'our aim in the following treatise' says Heidegger at the beginning of Being and Time $e^{(3)}$, 'is to work out the question of the sense of being and to do so concretely' [emphasis added] (p. 19). This 'concreteness' was realized in the form of characterizing the philosophical reflections he was presenting. He did not want to define and explain 'being', but he aimed at presenting a 'sense of being.' The 'sense' which Heidegger meant is only that 'in terms of which something becomes intelligible as something.' However, 'being,' for him, is not something like a being, it is 'what determines beings as beings, that in terms of which beings are already understood' (pp. 4-5).

However, he finds that there is no access to being other than via beings themselves, hence pursuing the question of being inevitably means asking about a 'being' with regard to its 'being'. This sense of being, as Heidegger claims, precedes any notions of how or in what manner any particular being or beings exist, it is pre-conceptual, non-propositional, and hence pre-scientific. He aimed at capturing the human existence in its actual being. In so doing he had to reverse the usual philosophical investigation cycle of the problem of 'being'. This cycle used to start with an absolute meaning of 'a universal being,' its essence and characteristics, then proceeded to investigate the other less universal identities that exist as part of that 'universal being' (Safadi, 1980, p. 7). 
Heidegger, instead, started, in an unprecedented shift in philosophical investigation of the human being, from the 'human being' as the only way to discover the essence of all existence (Safadi, 1980, pp. 7-8). He, then, comes to the conclusion that a true understanding of being can only proceed by referring to particular beings. This particular being represents the only way through which we can capture the meaning of being: 'the 'entity' asking the question; the inquirer as the subject of inquiry' (Tietz, 2001, p. 15).

Heidegger shows how failing to present that 'particular being' led philosophy to indulge into general ideas that could not account for 'being'. He values the answers presented by Plato and Aristotle concerning the question of 'being' in comparison to modern philosophy that overlooked the whole question. However, both Plato and Aristotle came out with some abstract conceptions of 'being' (Safadi, 1980, pp. 8-9). ${ }^{(4)}$ It was Hegel who first proposes to think of 'being' in developmental, organic imagery that undermined both types of metaphysics: the substance/attribute' metaphysics and the 'subject/object' metaphysics (Tietz, 2001, p. 11). Heidegger's critique of the traditional view is bound up with his attempt to articulate a new vision of human being. He believes that in investigating the question of 'being, we cannot detach the 'particular being' who alone can present an answer for the question of 'being' (Okrent, 1993, p. 291).

Thus, Heidegger proposes a 'particular being' in his book. He even goes further and names this character:

This entity which each of us is himself and which includes inquiring as one of the possibilities of its Being, we shall denote by the term "Dasein". If we are to formulate our question explicitly and transparently, we must first give a proper explication of an entity (Dasein), with regard to its Being. (1996, p. 27)

Dasein ${ }^{(5)}$ is, for Heidegger, a 'distinctive being.' It ${ }^{(6)}$ is for him 'the being that will give access to the question of the meaning of Being? ...the being for whom the question of Being is important, the being for whom Being matters'. Thus, the question of being turns from 'a what', into 'a who'. He assures that his mission in the book can be accomplished 'by appealing to a being which in conformity with its kind of being is suited to 'come together' with any being whatsoever.' This is why he considers that Dasein revealed itself to be 'that being which must first be elaborated in a sufficiently ontological manner if the inquiry is to become a lucid one' (1996, p. 12).

Derrida (1969) managed to capture the essence of Dasein in Heidegger's philosophy in his famous comment: 'We see, then, that Dasein, if it is not man, is not, however, other than man.' He considers Dasein 'the exemplary being for the hermeneutics of the sense of Being'[emphasis added] (p. 48). For Hubert L. Dreyfus, the first project carried in Being and Time is a powerful critique of a series of assumptions concerning "what it is to be a person'[emphasis added], along with the other project of presenting a compelling new interpretation of human being (Okrent, 1993, p. 290). Presenting Dasein in the book helps Heidegger carries both projects: 'Dasein consequently functions as the being that is to be interrogated fundamentally in advance with respect to its being' (1996, p. 12). 
Thus, from the very beginning of the book, we can start to sense that we are ahead of a reading experience of a philosophical book that sets the scene for a looming figure, a person, who is human-like: not 'man,' but nothing other than 'man,' a 'distinctive being' and an 'exemplary being.' A presentation that has the target, in Dreyfus's phrasing, of presenting and interpreting a 'person' about whom Dreyfus asks: 'Can this being, Dasein, be made transparent to itself? Can we understand its behavior?' (7)

The name given to that figure, Dasein, with its literal meaning, 'being-there', presupposes some existence in time and space. The fact that all translations of Heidegger's book kept using Dasein, capitalized, and not using a translated form of the word, ${ }^{(8)}$ though it has meaning, proves that those translators had the sense that they were dealing with a special construct whose character has to be integral. Marquarrie and Robinson (1962) gave the following note in their translation of Heidegger's book:

The word 'Dasein' plays so important a role in this work and is already so familiar to the English-speaking reader who has read about Heidegger, that it seems simpler to leave it untranslated except in the relatively rare passages which Heidegger himself breaks it up with a hyphen ('Da-sein') to show its etymological construction; literally 'Being-there'. (p. 27)

Tietz (2001) capitalizes Dasein all over his book, but does not capitalize 'being' except when it refers to an historical sense, such as Plato's or Aristotle's. 'Capitalization,' asserts Tietz 'makes it appear too noun-like, as if it referred to a thing' (p. 11). He comments on Heidegger's selection of this name:

Heidegger does not use 'person' or 'mankind' because these involve specific histories and interpretations. Dasein means 'being-there' in the sense of an activity. Dasein is a living being, one that acts. Dasein does not exist as a thing, or even a thing of a certain kind. Its identity is a function of its activity. (p. 16)

Heidegger wants a term that is as neutral as can be. Heidegger, of course, does not give any physical description of Dasein, and he is not supposed to do so; after all, it is a philosophical book not a fiction. However, the rest of the book provides many traits of that figure that helps construct an image that can be described as a 'fictional character'. Tietz asserts that although Dasein is not a particular representation of human life, it is not an abstract conception of the self either; it is not a philosopher's conception of the self (pp. 43-45).

The method Heidegger deployed in Being and Time can be described as an attempt to delimit the characteristics of Dasein. ${ }^{(9)}$ He did not intend to discuss Dasein as 'full-being,', he, instead, discussed Dasein as being-in-time-and space: a being without final realization. This technique, unprecedented as mentioned before, led some to accuse Heidegger of breaking down the human nature (Safadi, 1980, p. 9). The influence of the book proves that Heidegger characterization of a 'particular being' as a way to understand human existence was successful in presenting some key answers to the meaning of 'being.' Dasein lays bare the horizon for an interpretation of the meaning of being in general (Tietz, 2001, p. 23). Dasein differs from everything else in the universe because it interprets not only what it encounters but itself as well (Tietz, 2001, p. 17). Okrent (1993) highlights how Dasein is a being that self-intends and self- 
interprets (p. 293). Heidegger holds that 'Dasein finds 'itself' proximally in what it does, uses, expects, avoids-in those things environmentally available with which it is proximally concerned' (Heidegger, 1962, p. 155). ${ }^{(10)}$

Heidegger characterized Dasein by specifying four main personality models, that help construct a figure in the reader's mind. These personality models are: being-in-world, being-intime, living-by-activity, and living-to-an-end. By ascribing such personality models to Dasein, that include traits, states of mind, mental properties and features, (11) Heidegger managed to present in his work a character that can be easily remembered all the time Being and Time is mentioned.

Heidegger does not only locate Dasein in a world, but also considers Dasein as the activity of being-in-a-world (Safadi, 1980, p. 11). For Tietz, the expression 'being-in-a-world' is hyphenated to convey the unity of activity and world, to distinguish Dasein's kind of being from that of objects. In that world, Dasein is not an isolated, immaterial being but one related to other Daseins as well as to the things in its world through action. The basic activity of Dasein in the world is inquiry into being, especially into the nature of its own being (pp. 16-17). The question of existence for Dasein is answered by undertaking some activity, engaging in or doing something or even nothing at all. But Dasein is not like the things it analyzes. Dasein is closest to us and yet ontologically it is farthest because its being is largely concealed from itself. Because Dasein remains hidden from itself, or takes itself for granted, it tends to look at the world of entities as given rather than at how it understands them or why it understands them in this way (Tietz, 2001, pp. 20-23).

The Daseien's relationship to its world takes the form of 'care'. This concept establishes Dasein as a being fully engaged in daily life: 'everdayness'. It is always concerned with activities and with the future. Tietz (2001) highlights how all Heidegger's examples employ action-verbs (p. 24). Dasein is a functional concept dependent on its encounter with the world. Thus, Dasein is not independently identifiable: it must be understood in relation to its world (Safadi, 1980, pp. 910). Heidegger's book can be considered an answer to a big question concerning the problem of 'being' as caring (Kronegger, 1990, p. 115). Heidegger explains that he chose this term to designate the being of a possible being-in-the-world. We do not choose this term because Dasein is initially economical and 'practical' to a large extent, but because the being of Dasein itself is to be made visible as care. (1996, p. 53)

Heidegger establishes 'presence' as the predominant characterization of the world with two senses: to be 'present here and now', and to be 'present-at-hand' (or 'occurrent'). As Macquarrie and Robinson (1962) point out, this term, 'occurrent', designates the presence of things other than Dasein - the things making up the world, i.e. spatio-temporal objects (p. 418). Dasein has a kind of being different from the being of these kinds of entities (Tietz, 2001, pp. 3031). Dasein's reaction to what it confronts in the world takes two major states of the mind: 'dread' and 'fear' (Safadi, 1980, pp. 11-12). The difference can be stated simply if 'fear' is considered as directed at something specific, while 'dread' is about the world as a whole (Tietz, 2001, p. 85). Both states reveal the actual mode of Dasein's being-in the world.

Another very important personality model of Dasein takes prominence as Heidegger provides an interpretation of the temporality of Dasein. Hence, he called his book Being and 
Time. Time, as appears from the book's title, plays a major part in this account; it forms for Heidegger 'the 'horizon' for understanding being' (Tietz, 2001, p. 11). Time is actually what distinguishes Heidegger's structure of existence as 'existential;' to be differentiated from the other 'existentialist' accounts. Kaelin distinguishes the word 'existential' from 'existentialist;' the German word, Existentielle, has the specific denotation of the concrete act of existing. It refers to man's understanding of himself in his concrete historical and ontic situation (Kronegger, 1990, p. 113). Heidegger shows how these concepts, 'being,' 'care' and 'temporality' correlate in forming the character of Dasein:

Temporality is the meaning of the Being of care. Dasein's constitution and its ways to be are possible ontologically only on the basis of temporality, regardless of whether this entity occurs 'in time' or not. Hence Dasein's specific spatiality must be grounded in temporality. (1962, p. 418)

Heidegger rejected the idea of considering 'being' as an investigation into a timeless, eternal realm. He, instead, projected Dasein as located in history. Dasein must therefore understand the nature of time in order to understand 'being' and itself. It is to be understood as occurring in space and time (Tietz, 2001, pp. 23-24).

Dasein is also presented as a being with a sense of time. It has the ability to do the activity of connecting the past to the present, but, as all human being do, the future is the most important temporal orientation for Dasein. Being concerned about the future is what Heidegger calls 'projection.' Dasein can imagine itself in the future (Tietz, 2001, pp. 28-29). Dasein's projection to the future is an integral part of its being-in-the-world as well (Safadi, 1980, p. 16). 'Projection' and 'occurrence' are key terms used in the book. Their denotation of the realization of some concrete ideas into a physical form, along with its relationship with history, are aspects of the characterization of Dasein.

Heidegger agrees with many other philosophers that time is an objective feature of the world, however, he does not explain time by investigating the question of the subjective/objective distinction. (12) He, instead, explains it through presenting Dasein as 'activity'. This constitutes the third personality model Heidegger establishes in his book as one of the main characteristics of Dasein: living-by-activity. For Heidegger, it is not the 'working' of the mind that must be explained, but the behavior of Dasein, its activities rather than subjective inner states or a priori capacities (Tietz, 2001, pp. 26-27). Dasein is characterized by its action; however, Heidegger prefers activity to action as it encompasses 'passivity' as part of Dasein living:

Dasein is already acting. We are purposely avoiding the term 'action.' For in the first place, it would have to be so broadly conceived that activity also encompasses the passivity of resistance. (1996, p. 267)

Such act of presentation through activity is implicit characterization of the concept. In characterizing his concept of being, Dasein is distinguished from other temporal entities in the world. Being is 'made visible in its 'temporal' character' in the sense that time is part of the identity and character of things. Dasein is not 'in' time like a log floating down a river, it changes through its existence (Tietz, 2001, p. 27). Part of the social existence of Dasein is its 
communication with the world and the other identities around it. Language plays a major part in this respect. For Heidegger, language is a kind of equipment that takes different forms: idle talk (daily talks), curiosity (desire for knowledge), and ambiguity (lack of knowledge) (Tietz, 2001, pp. 96-98). ${ }^{(13)}$

Heidegger divides Dasein's activity into two main categories: 'authentic' and 'inauthentic.' 'Inauthenticity' has the sense of something that is not 'my own': I am inauthentic when I am not in control, when my values and beliefs are determined by others. 'Authenticity' is connected to self-awareness: it is an activity unique to Dasein. Heidegger makes Dasein's primary relation to the world through the 'knowing how,' 'ready to hand' use of equipment for its own ends. James Giarelli (2000) considers Heidegger's account of authenticity and inauthenticity as grounded in an analysis of different ways Dasein can pursue these ends (p. 11).

Heidegger also characterizes Dasein as a being with 'self-image,' 'personal identity' and 'awareness' (Tietz, 2001, pp. 29-32): attributes that are basic for a character. Dasein's 'selfimage' is a result of understand itself through its relations to its world. 'Personal identity' is not a given essence of a given mind, it is something that is achieved or created through Dasein's activity. This identity is established by awareness which he connects to 'Mineness' as a special kind of awareness constituting Dasein's self-identity. Giarelli highlights how Heidegger links the search for identity to the idea of an 'ability.' He postulates some projective identities that will be the result of this relationship: ' being-a-carpenter, being-a-parent, are more than mere skills; they constitute an 'aiming' of how and what we care to be' (p. 12).

The last aspect that can be established as part of the characterization of the concept of 'being' is its sense of 'death.' Death is the limit of Dasein's being-in the world: this inevitable encounter makes Dasein living-to-an-end. Death represents a personality model whose value is determined by 'conscience' and 'guilt' (Safadi, 1980, pp. 11,13). 'Conscience' makes Dasein accept responsibility for itself; while guilt determines the question of responsibility. Death, thus, forms the transcendental limit (horizon) for the temporality of life ('the end') (Safadi, 1980, p. 15). The relation between death and time is detailed by Tietz (2001) as follows:

The nature of Dasein and the potentiality for being (encountering the world) includes the end of being, of existence. Everydayness is that kind of being lying between birth and death. How does Dasein's coming to an end effect the conception of Dasein's being-awhole, the unity of Dasein? The problem of being towards death, the recognition that possibility entails finitude, one's own finitude. The end of life is part of the fore-structure of life. (p. 130)

Dasein's realization of its temporality and finitude through its encounter with the meaning of death as the end of its activity is the occasion for Dasein's reassessment of its nature and its selftranscendence (Tietz, 2001, p. 26).

Thus, Heidegger presents Dasein as mortal: 'stretched along' between birth and death, and thrown into its world with its possibilities which it is charged with the task of assuming. Dasein is presented as living on a continuum with two ends: birth and death:

It may be that as regards Being-towards-the-end the question itself may even have found its answer. But death is only the 'end' of Dasein; and, taken formally, it is just one of the 
ends by which Dasein's totality is closed round. The other 'end', however, is the 'beginning', the 'birth'. (p. 425)

With this focal trait of Dasein, temporality and the sense of death in its life, Heidegger managed to characterize a figure for 'being' through which the idea became concrete to his readers. Those readers, on their own part, managed, at the same time, to figure out an image that captured those philosophical reflections.

These are the personality models that construct on the readers' mind a figure that is, to a great extent, similar to many characters that fiction writers produce. I think Dasein is not less live or less human-like in the memory of those who read Heidegger's book, or even read about it, than many great characters in literary works. Although Heidegger did not tell us a story, his philosophical reflections in Being and Time span the human life in a way that visualizes some personality models that constitutes the corners around which our a 'character' is built.

\section{Conclusion}

Thus, "Dasein" stands out in Heidegger's Being and Time (1927) as a fictional character in a non-fictional writing. "Dasein" is constructed in the readers' mind as a figure of a persona about whom all the philosophical reflections are discussed. The way this persona is constructed in the book, the way it is conveyed to the reader, and the way the reader constructs an image of this persona while reading are all aspects of the fictional characters one can find in fictional narratives.

The grounds on which it can be claimed that Heidegger's discussion in his book produces a character have been explained. In addition, some explanation has been presented about how and why he resorts to this technique of fictional characterization in this highly influential philosophical book. The main aspects through which a 'fictional character' is constructed, or figured out, in readers' mind have been discussed to explain how it can be claimed that "Dasein" can be considered a 'fictional character' in the absence of a 'plot'. Four main personality models have been specified that help construct "Dasein" as a 'fictional character' in the reader's mind. These personality models are: being-in-world, being-in-time, living-by-activity, and living-to-anend.

\section{Notes:}

(1)'Persona' originally means 'mask.' It is used in literature to refer to the person who is understood to be part of a particular work. (See 'Persona,' Encyclopedia Britannica, www.global.britannica.com)

(2) Though Husserl, Heidegger's teacher, denied that phenomenology can work with existentialism, Heidegger managed to use the phenomenological approach to produce an existentialist philosophy (Safadi, 1980, p. 7).

(3) The German title is Sein und Zeit. There are two English translations: Being and Time. Trans. John Macquarrie and Edward Robinson (London: SCM Press 1962); and Being and Time: A Translation of Sein und Zeit Trans. Joan Stambaugh (Albany: State University of New York Press 1996). The present article will refer to the two English translations due to some differences in rendering some concepts in English and the valuable notes provided by the translators. 
(4) Safadi presents a detailed analysis (Safadi, 1980, pp. 8-9).

(5) Dasein is an ordinary German word literally meaning 'being-there.' Heidegger follows the everyday usage (the kind of Being that belongs to person), but often uses it to stand for any person who has such Being, and who is thus an 'entity' himself. (Heidegger, 1962, p. 27)

(6) The pronoun 'it' is used here to avoid any issue of gender as Dasein is meant to represent a neutral being.

${ }^{(7)}$ Quoted in (Tietz, 2001, p. 15).

${ }^{(8)}$ Even studies of Heidegger in other languages- I checked some resources in Arabic- use Dasein (transliterated) as a proper noun, not as a concept that can be translated in the language of the study.

(9) See (Tietz, 2001, p. 11) and(Safadi, 1980, p. 8).

(10) Derrida considers “proximity’ a key to reread Heidegger's book (Derrida, 1969).

(11) There is no direct discussion of the moral life of "Dasein" in Heidegger's book due to the absence of ethics in his philosophy. See (Safadi, 1980, pp. 10-12).

(12) The historical background of such questions about time goes back to Kant's argument that time is a 'form of intuition' and as such is 'subjective.' Time functions as a structural, organizational characteristic of the mind (Tietz, 2001, p. 26).

${ }^{(13)}$ See also (Safadi, 1980, p. 12).

\section{About the Author:}

Abdel-Fattah M. Adel is a PhD holder in English Literature (literary criticism and theory). He is the department chair at the University of Bisha, Saudi Arabia, where he teaches courses in literature and literary criticism. His main research interest is literary and critical theories. He is also interested incontemporary English literatureand theories of reading.

\section{References}

Abrams, M. H. (1999). A Glossary of Literary Terms, Seventh Edition. Boston: Heinle \& Heinle. Bradbury, M. (2006). Character. In P. Childs, \& R. Fowler, The Routledge Dictionary of Literary Terms (pp. 23-25). New York: Routledge.

Chatman, S. (1980). Story and Discourse: Narrative Structure in Fiction and Film. Ithaca: Cornell University Press.

Cixous, H. (1974). The Character of "Character". New Literary History, 383-402.

Cuddon, J. A. (1999). The Penguin Dictionary Of Literary Terms and Literary Theory, Fourth Edition. London: Penguin Books.

Derrida, J. (1969). The Ends of Man. Philosophy and Phenomenological Research, 31-57.

Giarelli, J. (2000). On the Metaphysics of Presence. Philosophy of Education, 11-14.

Heidegger, M. (1962). Being and Time(John Macquarrie and Edward Robinson, Trans.). London: SCM Press.

Heidegger, M. (1996). Being and Time: A Translation of Sein und Zeit (Joan Stambaugh, Trans.). Albany: State University of New York Press.

James, H. (1972). Theory of Fiction: Henry James ed. James Edwin Miller . Nebraska: The University of Nebraska Press.

Kronegger, M. (1990). Rev. of Heidegger's Being and Time, A reading for readers, by E. F. Kaelin. The American Journal of Semiotics, 113-116. 
Macquarrie , J., \& Robinson, E. (1962). Preface and Notes. In M. Heidegger, Being and Time (pp. 13-17). London: SCM Press.

Margolin, U. (1986). "The Doer and the Deed: Action as a Basis for Characterization in Narrative". Poetics Today, 205-225.

Margolin, U. (2007). 'Character'. In D. Herman, The Cambridge Companion to Narrative (pp. 66-79). Cambridge: Cambridge.

Okrent, M. (1993). Rev. of Being-in-the-World: A Commentary on Heidegger's Being and Time, Division I, by Hubert L. Dreyfus. The Philosophical Review, 290-293.

Rimmon-Kenan, S. (1983). Narrative Fiction: Contemporary Poetics. London: Routledge.

Safadi, M. (1980). 'Martin Heidegger and Being'. Contemporary Arabic Thought, 4-22.

Schwarz, D. (1989). 'Character and Characterization: An Inquiry'. The Journal of Narrative Technique, 85-105. write the volume and issue of the journal

Tietz, J. (2001). An Outline and Study Guide to Martin Heidegger's Being and Time. Frankfurt: Frankfurt am Main. Retrieved from Humanities Online http://www.humanities-online.de.

Weststeijn, W. G. (2004). 'Towards a Cognitive Theory of Character,' ed. In H. v. Fleishman, C. Gölz, \& A. Hansen-Löve, Analysieren als Deuten: Wolf Schmid zum 60 Geburtstag (pp. 53-65). Hamburg: Hamburg University Press. 